\title{
Albright's hereditary dystrophy: brain stones
}

\author{
Rajendra Singh Jain, Kadam Nagpal, Pankaj Gupta, Rahul Handa
}

Department of Neurology, S.M.S. Medical College, Jaipur, Rajasthan, India

\section{Correspondence to}

Professor Rajendra Singh Jain, drrsjain@yahoo.com, padayappa4u@yahoo.com
CrossMark

To cite: Jain RS, Nagpal K, Gupta P, et al. BMJ Case Rep Published online: [please include Day Month Year] doi:10.1136/bcr-2013203369

\section{DESCRIPTION}

A 20-year-old woman presented with frequent cramps in extremities with carpopedal spasms and recurrent episodes of generalised tonic-clonic seizures for the past 10 years. Two years previously she had undergone cataract surgery with lenticular implants in both the eyes. There was no history of any prolonged drug intake, fever, toxin exposure, chronic illnesses in the past or any significant family history for similar illness.

Examination revealed short stature, rounded face with generalised skin darkening, poor dentition, patchy alopecia and brachydactyly (figure 1). She also had demonstrable Chvostek's Grade III and Trousseau sign. Her haemogram was normal and biochemistry revealed normal serum albumin, low serum calcium $(8.0 \mathrm{mg} / \mathrm{dL})$, elevated phosphates $(7.5 \mathrm{mg} / \mathrm{dL})$, elevated parathormone levels $(200 \mathrm{pg} / \mathrm{mL})$ and normal thyroid profile. A CT scan of the head showed calcification involving bilateral basal ganglia, thalamus, dentate nucleus and subcortical white matter (figure 2). Ultrasound abdomen revealed a left renal cortical cyst and nephrolithiasis. X-rays of both the feet showed shortening of fourth metatarsal (figure 3) along with osteodystrophic features.

The diagnosis of Albright's hereditary osteodystrophy was considered. This clinical entity was diagnosed by Albright et al. ${ }^{1}$ Pseudohypoparathyroidism (PHP) type 1a is associated with constellation of clinical features collectively termed as Albright hereditary osteodystrophy (AHO). These features include short

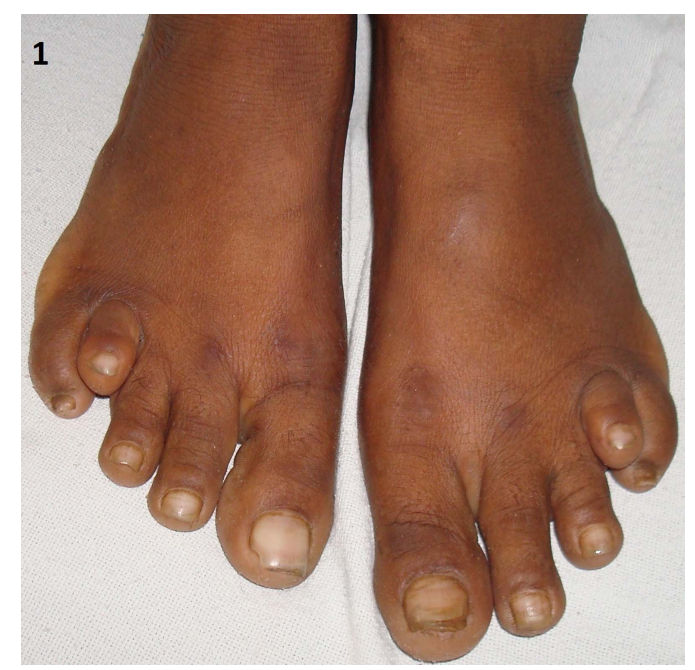

Figure 1 Foot photographs of the patient showing brachydactyly.

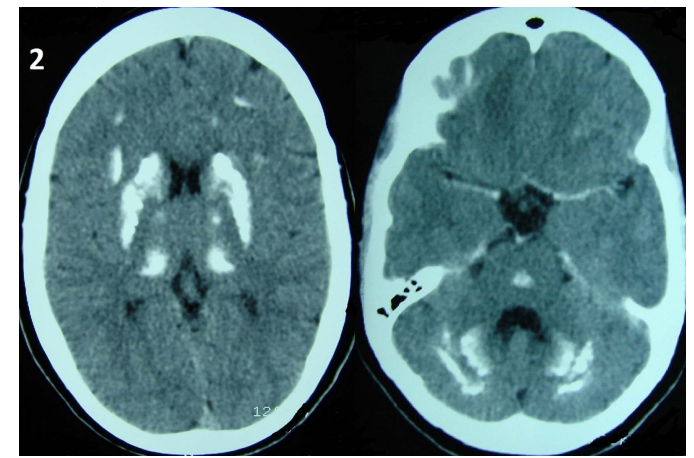

Figure 2 Non-contrast CT scan of the head showing bilateral basal ganglia, thalamic, pontine, dentate and subcortical calcifications.

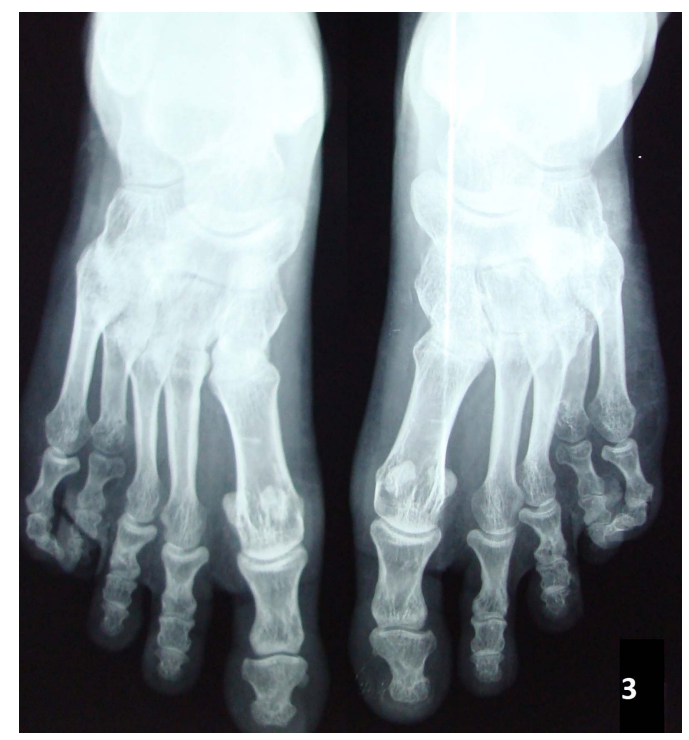

Figure 3 Digital X-ray of the feet (dorso-plantar view) showing bilateral shortening of fourth metatarsal.

stature, rounded face, brachydactyly, brachymetacarpia, centripetal obesity, subcutaneous ossifications, basal ganglia calcifications and, in some cases, mental or developmental delay. ${ }^{2}$ PHP is generally classified as types Ia, Ib, Ic and II according to different phenotypes and pathogenesis. AHO is often associated with pseudohypoparathyoidism, hypocalcaemia and elevated PTH levels (PHP Ia), as seen in our patient. Treatment of hypocalcaemia with calcium and vitamin D supplements is the mainstay, with routine screening of other associated endocrinopathy. 


\section{Learning points}

- Albright hereditary osteodystrophy constitutes constellation of brachydactyly, tetany, subcutaneous and basal ganglia calcifications with pseudohypoparathyroidism (PHP) type la.

- Low serum calcium, high phosphates and raised parathormone levels suggesting parathormone resistance are characteristics of this syndrome.

- Immediate correction of hypocalcemia with calcium and vitamin D supplements is of paramount importance.
Competing interests None.

Patient consent Obtained.

Provenance and peer review Not commissioned; externally peer reviewed.

\section{REFERENCES}

1 Albright F, Burnett $\mathrm{CH}$, Smith PH. Pseudohypoparathyroidism: an example of 'Seabright-Bantam syndrome'. Endocrinology 1942;30:922-32.

2 Levine MA. Pseudohypoparathyroidism: from bedside to bench and back. J Bone Miner Res 1999;14:1255-60.

Copyright 2014 BMJ Publishing Group. All rights reserved. For permission to reuse any of this content visit http://group.bmj.com/group/rights-licensing/permissions.

BMJ Case Report Fellows may re-use this article for personal use and teaching without any further permission.

Become a Fellow of BMJ Case Reports today and you can:

- Submit as many cases as you like

- Enjoy fast sympathetic peer review and rapid publication of accepted articles

- Access all the published articles

- Re-use any of the published material for personal use and teaching without further permission

For information on Institutional Fellowships contact consortiasales@bmjgroup.com

Visit casereports.bmj.com for more articles like this and to become a Fellow 